15 Bennett W M, Strong D. Arthralgia after highdose steroids. Lancet 1975; i: 332

16 Kurki P. The effects of "pulse" corticosteroid therapy on the immuno system. Scand $\mathcal{f}$ therapy on the immuno system.

17 Silverman E D, Myones B L, Miller J J. Lymphocyte subpopulation alterations by intravenous megadose pulse methylprednisolone. f Rheumatol 1984; 11: 287-90.

18 Newmark K J, Mitra S, Berman L B. Acute arthralgia following high-dose intravenous methylprednisolone therapy. Lancet 1974; ii: 229.

19 Trede N, Nielsen L P, Andersen V. Bradycardia after high-dose intravenous methylprednisolone therapy. Scand $\mathcal{F}$ Rheumatol 1986; 15: 302-4.

20 Kirk A P, Pitt P I, Kenny D, Berry H. Methylprednisolone infusion in rheumatoid arthritis. Br $\mathcal{F}$ Rheumatol 1985; 24: 119.

\section{Cyclosporin in Wegener's granulomatosis with renal failure}

Sir: In 1987 we presented in this journal the case history of a patient with Wegener's granulomatosis, in whom remission of the disease was achieved with cyclosporin. ${ }^{1}$ Now, after more than three years' treatment with this immunosuppressive drug no further activity of the disease has occurred. Although we stated that cyclophosphamide is still the drug of first choice in the treatment of Wegener's granulomatosis, this positive experience persuaded us to start cyclosporin treatment in another patient with Wegener's granulomatosis resistant to conventional treatment. As the effect of cyclosporin in this patient was even more impressive than it had been in the previous subject we feel it is worth reporting this case history.

In 1982 a 72 year old women was admitted to our hospital for evaluation of cough, rhinorrhoea, fever, and fatigue. Laboratory tests showed a raised erythrocyte sedimentation rate (ESR) of $122 \mathrm{~mm} / \mathrm{h}$, thrombocytosis (platelets $625 \times 10^{9} / 1$ ), and normal renal function. An $x$ ray examination of the chest and sinus showed no abnormalities. Histopathological examination of a biopsy specimen of the nasopharynx, however, showed destructive granulomatous reaction with necrotising vasculitis, characteristic of Wegener's granulomatosis. Consequently, treatment with cyclophosphamide (100 mg/day) and prednisone (30 mg/day) was started. Six weeks later her clinical condition and laboratory indices had normalised. During the following month the doses of both drugs were tapered slowly, with success.

Unfortunately she withdrew from further outpatient clinic control until she was admitted to hospital again in 1986 because of severe fatigue and depression. By that time she had stopped taking prednisone but continued with cyclophosphamide $100 \mathrm{mg} /$ day. Laboratory examination showed a raised ESR $(83 \mathrm{~mm} / \mathrm{h})$ anaemia (haemoglobin $93 \mathrm{~g} / \mathrm{l}$ ), low platelet count $\left(78 \times 10^{9} / 1\right)$, increased serum creatinine ( $156 \mu \mathrm{mol} / \mathrm{l})$, and haematuria (15-30 erythrocytes in the urinary sediment); testing for the presence of antineutrophil cytoplasmic antibodies was not done at that time. Her raised ESR and renal failure were considered as markers of activity of Wegener's granulomatosis; anaemia and low platelet count were thought to be manifestations of bone marrow depression due to cyclophosphamide. The administration of cyclophosphamide was stopped and prednisone $30 \mathrm{mg} /$ day was given. Nevertheless, her clinical condition deteriorated and serum creatinine rose to $365 \mu \mathrm{mol} / 1$. The corticosteroid regimen was changed to methylprednisolone $1500 \mathrm{mg}$ every other day intravenously for 10 days and the addition of azathioprine $25 \mathrm{mg}$ every eight hours, but this did not prevent further progression of renal failure and further rise of serum creatinine to $516 \mu \mathrm{mol} / \mathrm{l}$.

As Wegener's granulomatosis seemed to be progressive despite intensive treatment we decided-after informed consent of the patient-to start treatment with cyclosporin 5 $\mathrm{mg} / \mathrm{kg}$ body weight a day and prednisone 40 $\mathrm{mg} /$ day. Trough concentrations of cyclosporin (by radioimmunoassay and measured in whole blood) ranged from $405 \mathrm{ng} / \mathrm{ml}$ to $780 \mathrm{ng} / \mathrm{ml}$. One month later her condition had clearly improved, with decreased values of ESR (48 $\mathrm{mm} / \mathrm{h})$ and serum creatinine $(213 \mu \mathrm{mol} / \mathrm{l})$ During the following period cyclosporin trough concentrations were kept at about 600 $\mathrm{ng} / \mathrm{ml}$, and prednisone was tapered slowly. More than two years after the initiation of cyclosporin this patient, who at that time was aged 79 , is doing very well with stabilised serum creatinine concentrations of 190-210 $\mu \mathrm{mol} / \mathrm{l}$ and no antineutrophil cytoplasmic antibodies.

In this case of Wegener's granulomatosis cyclosporin seems to have been effective Interestingly, improvement of renal function was achieved by treatment with an immunosuppressive drug for which nephrotoxicity is the most prominent side effect. This observation fits with another case report showing the beneficial influence of cyclosporin in a patient with Wegener's granulomatosis with renal failure. ${ }^{2}$ Obviously, cyclosporin is an alternative to cyclophosphamide in treatment of patients with Wegener's granulomatosis. Additional studies are necessary to confirm the precise role of cyclosporin in the treatment of this disease.

$$
\begin{array}{r}
\text { J C C BORLEFFS } \\
\text { University Hospital } \\
\text { Department of Internal Medicine } \\
\text { Division of Immunopathology } \\
P O \text { Box } 85500 \\
3508 \text { GA Utrecht } \\
\text { The Netherlands } \\
\text { J C VAN DER ZWAN } \\
\text { Hospital 'De Lichtenberg' } \\
\text { Department of Internal Medicine } \\
\text { Utrechtseweg 160 } \\
3818 \text { ES Amersfoort } \\
\text { The Netherlands }
\end{array}
$$

1 Borleffs J C C, Derksen R H W M, Hené R J. Treatment of Wegener's granulomatosis with cyclosporin. Ann Rheum Dis 1987; 46: 175. 2 Gremmel F, Druml W, Schmidt P, et al. Cyclosporin in Wegener's granulomatosis. Ann Intern Med 1988; 108: 491 .

\section{Anaerobic bacteria in rheumatoid arthritis}

Sir: In past years some rheumatologists have thought that anaerobic bacteria have a role in the pathology of rheumatoid arthritis.

We considered that if anaerobic bacteria were essential to metabolism in the diseased joint then it should be possible to measure substantial amounts of their metabolic products-short chain fatty acids-in the synovial fluid.

We used a modification of McArthur's gas chromatographic method ${ }^{2}$ to examine 11 normal synovial fluids obtained during negative explorations on knees for meniscal disease and 15 fluids taken from the knees of patients with classical or definite rheumatoid arthritis. The synovial fluid samples were treated with hyaluronidase, then the short chain fatty acids were extracted with ether and freeze dried at $-80^{\circ} \mathrm{C}$. Before injection into the gas chromatograph the freeze dried material was redissolved in $8 \mathrm{M}$ formic acid. 2-Ethylbutyric acid was used as an internal standard.

The mean concentrations (range) of short chain fatty acids in normal fluid were found to be: acetic acid $102(54-149) \mu \mathrm{mol} / \mathrm{l}$; propionic acid $13(0-31) \mu \mathrm{mol} / \mathrm{l} ;$ n-butyric acid 3.4 (0-9) $\mu \mathrm{mol} / \mathrm{l}$; n-valeric acid 3.6 (0-18) $\mu \mathrm{mol} / \mathrm{l}$. There were no significant differences between normal and rheumatoid synovial fluids.

Thus it seems that the direct action of anerobic bacteria - for example, Clostridium perfringens and others, which produce short chain fatty acids, is excluded.

Ib ANDERSEN Immunochemistry Departmen Novo-Nordisk A/S 2820 Gentofte Denmark

HANS PETER OLESEN Rheum Spec 1954 Frederiksberg $C$ Copenhagen

1 Midtvedt $\mathrm{T}$. Intestinal bacteria and rheumatic disease. Scand 7 Rheumatol 1987; suppl 64: 49-54.

2 McArthur B, Sarnaik A P, Mitchell R A. Shortchain fatty acids and encephalopathy of Reye's syndrome. Neurology 1984; 34: 831-4.

Treatment of polymyalgia rheumatica and giant cell arteritis

Sir: We read with interest Kyle and Hazleman's article on the treatment of polymalgia rheumatica and giant cell arteritis,' which sheds some light on the problems of treatment in these two conditions. We would support their views that the lowest doses of steroid possible should be used both in the initial and maintenance treatment, but would like to draw attention to the possible dangers of undertreatment of the ophthalmic manifestations of giant cell arteritis.

Although doses may indeed be to some extent based on tradition and anecdote, in such a capricious and visually devastating condition it is anecdotal exceptions to which attention must be directed if the opportunity to prevent visual loss is to be taken.

The fact that the 'high dose' group had fewer episodes of relapse than the 'low dose' group, but still suffered a significant therapeutic failure rate, implies that even higher dose regimens should be considered. Ophthalmologists usually use much higher doses of steroid, at least initially, when treating patients who present with the visual sequelae of giant cell arteritis. ${ }^{2}$ Although quite probably most cases of giant cell arteritis might be managed with a lower dose even than $40 \mathrm{mg}$ prednisolone initially, success in the majority is not the ultimate aim of treatment, when the fate of the rest may be irreversible visual loss.

Sadly, the acute ischaemic optic neuropathy resulting from giant cell arteritis is often bilateral, with the second eye being affected very shortly after the first. A recent review of 50 cases of anterior ischaemic optic neuropathy related to giant cell arteritis ${ }^{3}$ found that when large doses of steroid (80-120 mg prednisolone initially, followed by the same dose for several days after) were used $95 \%$ of patients were protected from disease in the 